\title{
Distance Learning for New Students in the Era of Pandemic Coronavirus Disease (Covid-19): Implementation and Barriers
}

\author{
Sigit Priatmoko ${ }^{1, *}$, Wiku Aji Sugiri ${ }^{2}$, Bashori $^{3}$, M. Irfan Islamy ${ }^{4}$ \\ ${ }^{1,2,3}$ Universitas Islam Negeri Maulana Malik Ibrahim Malang, Indonesia \\ ${ }^{4}$ Universitas Islam Negeri Banjarmasin, Indonesia \\ "Corresponding author. Email: sigitpriatmoko@uin-malang.ac.id
}

\begin{abstract}
The implementation of distance learning during a pandemic era faces various obstacles. This study explores information about how the implementation of distance learning to first semester of freshment students (new students) and what obstacles they face. This research is a descriptive qualitative research. The data sources consisted of new students, lecturers, and learning result documents. The data were collected by distributing questionnaires using Google Forms, interviews, and document studies. The study results show that the massive application of distance learning in the State Islamic University of Maulana Malik Ibrahim Malang began in March 2020. It coincides with the spread of the coronavirus in Malang City. The data reveals that, the implementation of distance learning can be grouped into five categories, namely effective, moderately effective, casual, less effective, and ineffective. The six most frequently complained problems were the low quality of the internet connections, the much spending of buying internet data, the fatigue due to staring at the devices' screen for too long, the difficulty in accessing references, the poor communications, and the lack of materials comprehension explained by lecturers. However, these six obstacles do not entirely affect the respondents' motivation to learn. As a consequence, improvements in the quality of infrastructure and services have to be carried out to maximize the quality of distance learning.
\end{abstract}

Keywords: Distance Learning, New Student, Pandemic Era

\section{INTRODUCTION}

The COVID-19 pandemic has caused turbulence to several life sectors, including the education sector. Due to the virus experienced by Indonesia, started from March 2020 , the government has immediately issued an order to implement regional quarantine and social restrictions to prevent the spread of the virus. This instruction was then followed up by the Ministry of Education and Culture (Kemendikbud) by issuing a policy of implementing distance learning. This policy must be implemented by all level of educational institutions without any exception, including higher education institutions.

Responding to this policy, all universities immediately closed their campuses and shifted teaching and learning activities from face-to-face delivery to distance mode using the internet, including the State Islamic University of Maulana Malik Ibrahim Malang distance learning in the respective university is delivered via synchronous and asynchronous model using various platforms and/or applications such as Zoom, Google Meet, Google Classroom, and Edmodo. The social media patforms such as Whatsapp, Facebook, Email, and Youtube are also used as the learning media [1], [2].

In its development, the policy of implementing distance learning in higher education raises complex problems. Students, lecturers, campuses, and parents are complaining about it by [3]. Some of the obstacles often complained are the lack of distance learning infrastructure,[4] the cost of buying expensive internet data, the absence of devices, and the low acceptance of technology for lecturers and students. Other problems 
that have been complained are the decline in the quality of learning, the difficulty to instill positive values and develop students' good character, the lack of interaction between lecturers and students, and students with their classmates, and the lecturers' misconceptions about distance learning, where learning contains too many assignments. As stated by Galusha, the implementation of distance learning is generally constrained by; costs and motivators, feedback and teacher contact, student support and services, alienation and isolation, and lack of experience, and training [5].

Studies on distance learning during the COVID-19 pandemic tended to portray descriptively-analytically of three aspects. The first aspect is closely related to the effectiveness of distance learning in achieving learning goals, including how to use the learning management system [6], [7]. The second is about the constraint aspects which include infrastructure, psychological, and system constraints [8]. The third aspects relates to students' experience in distance learning. The example of it is, students' readiness to welcome distance learning and their level of motivation in taking distance learning [9]. The subjects of these studies are carried out in general; nothing has been focused on first semester frehment students (new students).

This study aims to complement previous studies by focusing on distance learning for new students and what obstacles they face. The urgency of discussing this issue is based on an assumption that new students face relatively more obstacles in participating in distance learning compared to students who have experience in taking distance learning. Apart from the mastery of technology, the new students have to immediately adapt to higher education's learning model. This factor is important to determine the readiness of new students to take the distance learning. The results are expected to describe whether the distance learning has an impact on new students' motivation and learning outcomes.

\section{METHOD}

This research is a descriptive qualitative research. The research was conducted at the Faculty of Tarbiyah and Teacher Training (FITK), the State Islamic University of Maulana Malik Ibrahim Malang. The issue raised was the implementation of distance learning for new students and the obstacles they face in taking distance learning.

The data sources are divided into two, the primary and secondary data sources. The primary data sources are informants consisted of crucial informants, the new students of FITK batch 2020/2021, and supporting informants, the lecturers teaching new students' classes. The secondary data sources are the assignment documents and new students' grades.
The data were collected by distributing questionnaires, doing interviews, and collecting supplementary documents. The questionnaire method was used to collect data from key informants to study their responses about obstacles, and/or difficulties during distance learning implementation. The questionnaire was prepared in an open format, so, the respondents were freely expressing their opinions. The questionnaires utilized Google Form due to COVID-19. Meanwhile, the interviews were used to collect data from supporting informants. The document study was used to compare the results of questionnaires, the interviews results with documents such as assignments and a list of scores.

The collected data was then analyzed using Miles and Huberman's interactive analysis, which consisted of stages, namely data, data deposition, data presentation, and conclusion drawing. After collecting raw data, coding, selection, focusing, simplification, and abstract are done. The next step is to present the data into matrices, graphs, or tables. The finally step is drawing conclusion.

\section{RESULT AND DISCUSSION}

\subsection{Implementation of Distance Learning to New Students}

Distance education is the most well-known term used to describe distance learning. This term describes efforts to provide access to learning for those who are geographically far from educational institution sites. Over the past two decades, the relevant literature suggests that various authors and researchers use inconsistent definitions of distance education and distance learning [10]. Even though the coverage is different, the two are interchangeable [11]. Distance education has a broader scope than distance learning because distance learning is an integral part of distance education. As Keegan stated, distance education is the term "umbrella," which is in common with the terms correspondence education or correspondence studies that may have been used synonymously. It is clearly identified as a potential descendant of distance education [10].

During its development, e-learning has also emerged, which refers to the involvement of internet-based digital technology to support learning. According to Hartanto, elearning has three characteristics and they are a type of learning that is carried out via the internet network, needs the availability of learning support devices, such an external hard disk, a flash disk, a CD-ROM, and the requieres availability of tutor support services that can help students if they experience difficulties [12]. These days, distance learning in industrial revolution 4.0 is mostly based on the Internet of Things (IoT), Big Data, and Cloud Computing. The process of delivering learning materials, assigning and collecting assignments, and providing feedback are carried out through various 
platforms or applications integrated with cloud storage systems.

Distance learning is becoming one of the fastestgrowing fields of education. It impacts all education delivery systems. The development of Internet-based information technology and, in particular, the World Wide Web are the examples. Distance learning makes education become more flexible in the allocation of time, have no geographic restrictions, is cost/value competitive, and leads a learner-centered type of learning to face the changing world's needs [13].

Massive distance learning in the State Islamic University of Maulana Malik Ibrahim Malang began in March 2020. It is coinciding with the entry of the Coronavirus in Malang City. Until entering the new academic year, distance learning was still being applied because of the number of COVID-19 cases increased. Previously, not all lecturers applied this learning model. Although, the campus management has provided the Learning Management System (LMS) facility. Due to its sudden application, many problems arose. Miscommunication between lecturers and students, lack of preparation experienced by lecturers, and lack of LMS mastery both students and lecturers are the examples.

One of the parties that get many challenges due to distance learning is the new students. They have to adapt to the learning patterns and systems in higher education, which are different from the learning system that experienced prior to university. On the other hand, they must also immediately get used to learning using a distance learning model that requires the availability of supporting facilities such as internet networks, computer based devices and mastery of LMS or other learning platforms used.

The management of this campus issued various policies to minimize the various obstacles that arise, such as (1) giving tuition fee discounts [14], (2) providing data package assistance to students [15], (3) improved elearning performance as the main LMS [16], and (4) increase lecturers' competence related to distance learning [17]. However, it turned out that these policies were not able to make distance learning run effectively.

Based on data taken from the questionnaires, the implementation of distance learning for new students can be grouped into five categories, namely effective, moderately effective, casual, less effective, and ineffective. We can see the distribution of data for these five categories in Figure 1 below.

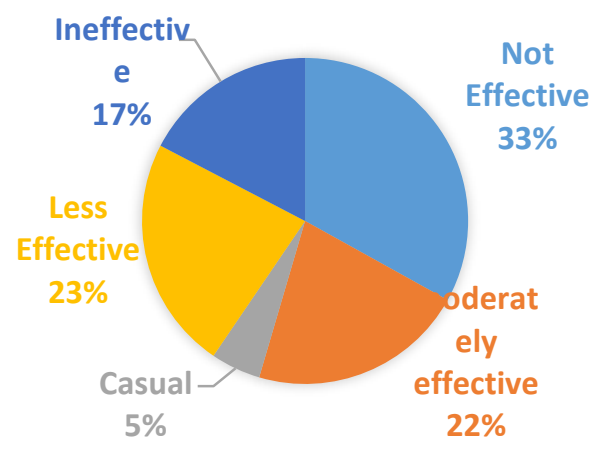

Figure 1. Implementation of Distance Learning for New Students

Looking at the data above, the majority of respondents stated that distance learning has been significant. However, that does not mean without obstacles. The majority of respondents complained about the low quality of the internet network because most of them live in rural areas. The learning platforms used vary, depending on the lecturer's instructions or class agreement. The primary consideration is the ease of access. The data shows that there are at least seven platforms are used, namely E-Learning, Zoom, Google Meet, Google Classroom, Whatsapp, Telegram, and Youtube.

Regarding campus support for the application of distance learning, majority of respondents stated that the campus had provided adequate support. Figure 2 below illustrates the findings.

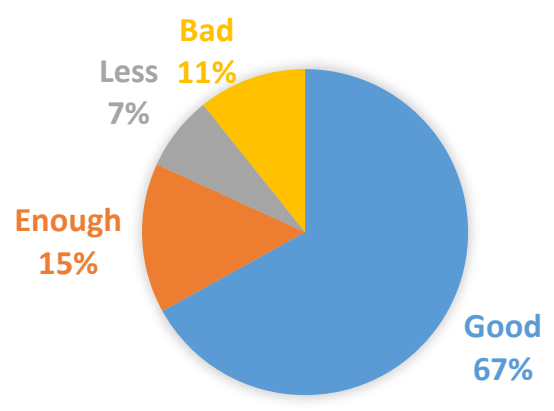

Figure 2. Campus Support

The form of support provided by the campus was providing quotas or internet data packages that students used to access learning platforms. Besides, the support was also in the form of providing an LMS that is developed by the State Islamic University of Maulana Malik Ibrahim Malang, namely E-Learning. Lecturers also provided support through giving motivation, loosing deadlines for assignment collection, providing reexplanations, opening a discussion forum outside lectures, and providing alternative learning models that did not burden students. The existence of support plays a vital role in students' acceptance in distance learning. As 
with the findings of Ahmad Abu-Al-Aish and Steve Love which stated that in addition to performance expectations and effort expectations, the influence of lecturers, service quality, and personal innovation are also significant factors that influence behavioral intention to use $\mathrm{m}$ learning, which in this case can analogous to distance learning [18].

\subsection{Constraints for New Students in Participating in Distance Learning}

Massive application of distance learning in Indonesia was carried out during the COVID-19 pandemic. This sudden application raises various problems stemming from unpreparedness, both from the government, schools, and the community [8]. Although statistically, the use of the internet as the basis for distance learning continues to increase, the quality of internet network is still a significant obstacle for distance learning.

APJII (Association of Indonesian Internet Service Providers) reported that in 2018, Indonesia's internet users reached $64.8 \%$ of around 171.17 million people. Based on this report, $92.6 \%$ of Indonesian students are active internet users. Unfortunately, many internet users are not supported by the quality of the infrastructure. The low quality of internet infrastructure becomes a significant obstacle to the implementation of distance learning.

According to questionnaires results, new students faced various obstacles when participating in distance learning. Every student not only faces one obstacle, but several obstacles. The data below contain all the obstacles faced by new students of this research respondents. The magnitude of the numbers shows the frequency which the constraints arise.

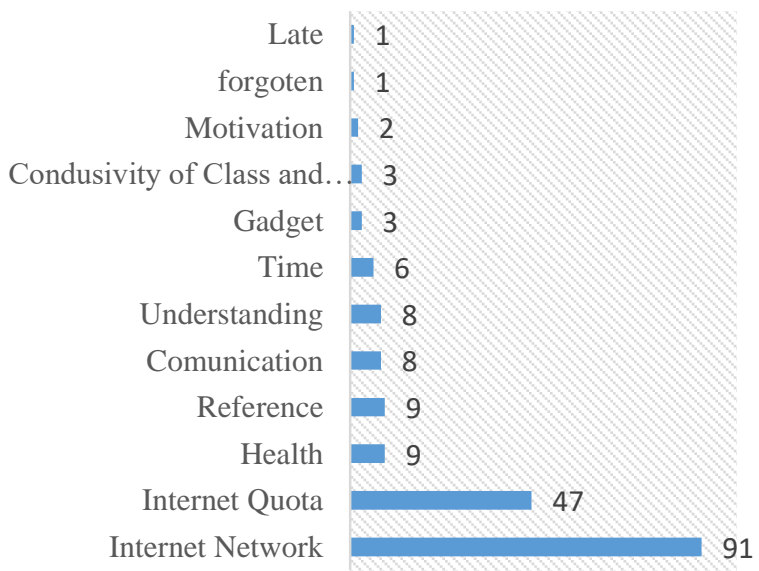

Figure 3. Distance Learning Barriers

Based on Figure 3 above, the two main obstacles to distance learning for new students are the quality of the internet network and the availability of internet data. The network quality is related to infrastructure, which is the domain of the government. This includes the adequacy of BTS (Base Transceiver Station) towers and frequent power cuts. The interviews conducted with lecturers who taught classes also obtained similar data. The seven lecturers who became informants agreed, that the internet network's quality was the main obstacle for new students. As stated by ANA:

"Not all students live in a place that is supported by a good network. So that some students are constrained by the network when attending online lectures."

This obstacle experienced in various regions, especially in rural areas. A survey was conducted in Jun. 25 to Jul. 012020 by Agustinus Subarsono in Yogyakarta province showed that out of 1,304 respondents, 50\% complained about the quality of the internet network [20], [21]. In this case, the Minister of Education and Culture, also acknowledges that the internet network's quality is the main obstacle to implementing distance learning [22].

Meanwhile, the internet data is related to costs. The majority of respondents complained about the high spending they had to buy internet data. The price can be many times higher than in normal conditions, before the pandemic happened. The high expenditure for internet data was caused by frequent teleconferencing lecture models and accessing video via Youtube or downloading large size materials.

Health is nother obstacle. It happens due tostaring at the devices (laptop and cellphone) for too long. Respondents also complained a lot about difficulties to access to references since bookstores were not always available in the area where students lived. Besides, communication often choked up due to the low quality of the internet network, making it difficult to fully understand the materials studied.

These various things significantly affect the respondents' enthusiasm and motivation in teaching and learning. These effects of obstacles can be seen in Figure 4 below.

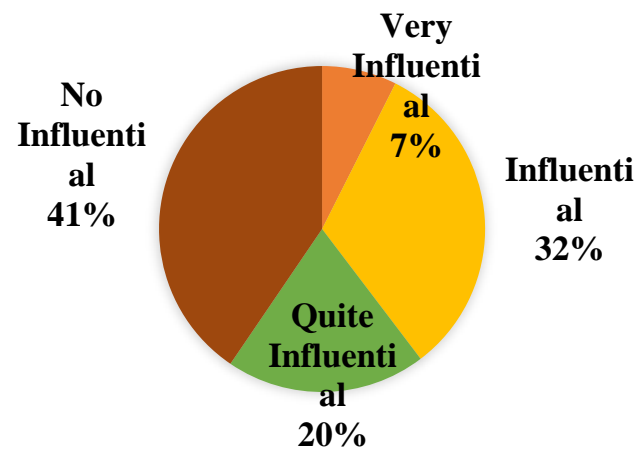

Figure 4. Impact of Constraints on Motivation and Learning Outcomes 
According to the lecturers as the informants in this study, these various obstacles did not significantly affect students' motivation and learning outcomes. As stated by NC:

"For learning outcomes and motivation, it seems that they are not affected by the assignments that are always collected on time by students"

However, the various constraints mentioned above indicate that, in general, the infrastructure to support distance learning in Indonesia is not sufficient. If basic needs such as internet networks does not suffice the needs, it will be difficult for any university to effectively apply distance learning. However, the COVID-19 pandemic has forced Indonesian education systems to jump several steps forward.

\subsection{Improve the Quality of Distance Learning}

The emergence of the industrial revolution 4.0 has undergone an educational revolution. Education has now shifted to education 4.0, where the Internet of Things (IoT), Big Data, and Cloud Computing are an integral part of learning process. Classrooms are now much more flexible, not limited to physical buildings, but have shifted to virtual spaces. Learning resources are abundant. It can be accessed anywhere and anytime as long as there is a device connected to the internet [12]. Education 4.0 seeks to harmonize people and technology and find new opportunities that are beneficial for common goods [23].

The COVID-19 pandemic that started in Wuhan district, China, has made this education shift progress even faster, especially for developing countries like Indonesia. Previously, only several educational institutions implemented internet-based distance learning. Now, all educational institutions implementi distance learning. However, it turns out that many obstacles hinder, as discussed in the previous section.

To overcome these various obstacles, it requires synergy from various parties, such as government, educational institutions, non-government organizations (NGOs), private sectors, and community. The government needs to provide necessary infrastructure to improve the quality of the internet network, so that, complaints related to bad internet signals are no longer exist. In Addition, the government must also distinguish between any forms of technology that students have access to, and technologies that are available to an institution or organization [24] hoping that any the procurement of infrastructure is right to the target.

Apart from the government, universities also need to reconstruct responsive and adaptive policies to accelerate technological developments, for example, by providing and optimizing LMS, as well as providing trainings for lecturers, educators, and students related to operating
LMS [25]. This is closely connected to digital literacy mastery, namely knowing, searching, understanding, analyzing, and using digital technology [26].

JISC (Joint Information Systems Committee) defines digital literacy as abilities that suit individuals to live, study, and work in a digital society [27]. In JISC's view, digital literacy is a capability that includes seven elements; media literacy, communication and collaboration, career and identity management, ICT literacy, learning skills, digital scholarship, and information literacy [28]. These seven elements is described in Figure 5 below.

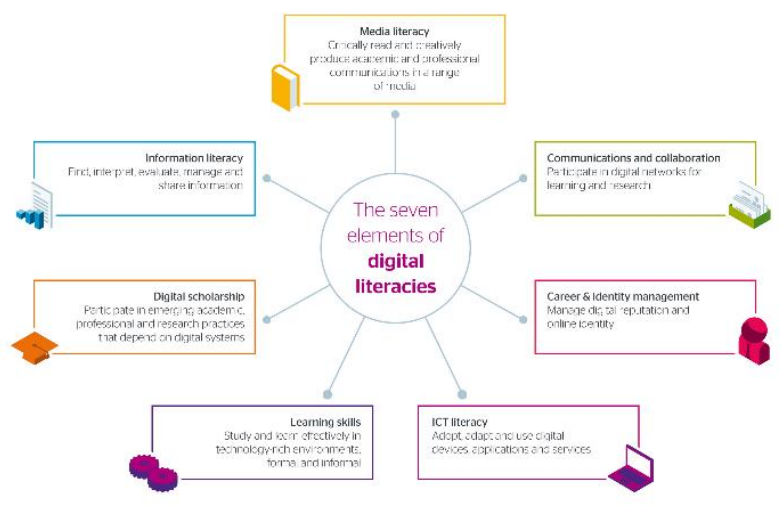

Figure 5. Elements of Digital Literacy

The mastery of digital literacy enables lecturers and students to carry out academic activities based on digital technology well. Digital literacy help them to critically analyze e-resources based on the up-to-dateness, suitability, ownership of information sources, accuracy, and purpose of the information to be used. [29]. Second, it builds communications through various media. Third, it boots participation in digital networks for research and learning. Fourth, digital literacy helps managing digital identity and reputation. Fifth, digital literacy leads lecturers and students to adopt, adapt and use various digital media. Sixth, it allows them to study in a technology-rich environment. Seventh, digital literacy support participation in generating practical research based on digital systems. Finally, digital literacy assists them to find, evaluate, interpret, and manage information.

In students' context, the application of distance learning is actually in line with the educational paradigm in higher education, where students are given the freedom to be actively participate in building the knowledge they need themselves. This is because university students are not the same as students in schools who have not fully mature in their thinking and emotions. University education is designed to expose students to something (sometimes even radically) new, which forces and/or invites them to change (adults) as human beings [30]. 


\section{CONCLUSION}

The application of distance learning to new students at the State Islamic University of Maulana Malik Ibrahim Malang is an effort to prevent the spread of COVID-19. Based on the research results, new students had to face several obstacles when participating in distance learning. The six most frequently complained problems are the low quality of the internet network, the cost of buying internet data, the fatigue due to staring at the devices' screen for too long, the difficulty accessing references, the poor communication, and not understand the material explained by the lecturer. These six constraints do not entirely affect the respondents' motivation to learn. However, quality improvement is still needed so that it can maximize the implementation of distance learning. The government, needs to revitalize the infrastructure as it an urgent matter. Universities has to improve academic services and boost lecturers' technological competence, students, and staff's digital literacy. This research is still a descriptive one. Further, a more in-depth research is needed to apply distance learning to undergraduate students with different approaches and points of view, so that, it can be seen how far the impact of distance learning to those students.

\section{REFERENCES}

[1] F. Firman, "Dampak Covid-19 terhadap Pembelajaran di Perguruan Tinggi", BIOMA: Jurnal Biologi dan Pembelajarannya, 2(1) 14-20, 2020.

[2] E. Permadi, "Ratusan Kampus di Sumatra Kesulitan Keuangan Akibat Pandemi", Bisnis.com, Pekanbaru, Sep. 04, 2020.

[3] W. A. Prodjo, "Perguruan Tinggi Bisa Mati karena Covid-19, Ini Penyebabnya...", Kompas.com, Jun. 27, 2020.

[4] R. Anggraeni, "Bank Indonesia Soroti Minimnya Infrastruktur Belajar Daring", Sindonews.com, Jakarta, Sep. 30, 2020.

[5] J. M. Galusha, Barriers to learning in distance education, 1998.

[6] W. Darmalaksana, R. Hambali, A. Masrur, and M. Muhlas, 'Analisis Pembelajaran Online Masa WFH Pandemic Covid-19 sebagai Tantangan Pemimpin Digital Abad 21', Karya Tulis Ilmiah (KTI) Masa Work From Home (WFH) Covid-19 UIN Sunan Gunung Djati Bandung, pp. 1-12, 2020.

[7] R. Pakpahan and Y. Fitriani, "Analisa Pemanfaatan Teknologi Informasi dalam Pembelajaran Jarak Jauh di Tengah Pandemi Virus Corona Covid-19", Journal of Information System, Applied, Management, Accounting and Research, 4(2) pp. 30-36, 2020.
[8] R. H. S. Aji, 'Dampak Covid-19 pada Pendidikan di Indonesia: Sekolah, Keterampilan, dan Proses Pembelajaran', Salam: Jurnal Sosial dan Budaya Syar-i.(7), vol. 5, pp. 395-402, 2020.

[9] D. R. A. U. Khasanah, H. Pramudibyanto, and B. Widuroyekti, 'Pendidikan Dalam Masa Pandemi Covid-19', Jurnal Sinestesia, vol. 10, no. 1, pp. 4148, 2020.

[10] J. L. Moore, C. Dickson-Deane, and K. Galyen, 'eLearning, online learning, and distance learning environments: Are they the same?', The Internet and Higher Education, vol. 14, no. 2, pp. 129-135, 2011.

[11] L. Sherry, 'Issues in distance learning', International journal of educational telecommunications, vol. 1, no. 4, pp. 337-365, 1995.

[12] B. Indrayana and A. Sadikin, 'Penerapan ELearning di Era Revolusi Industri 4.0 untuk Menekan Penyebaran Covid-19', Indonesian Journal of Sport Science and Coaching, vol. 2, no. 1, pp. 46-55, 2020.

[13] M. Bušelić, 'Distance Learning-concepts and contributions', Oeconomica Jadertina, vol. 2, no. 1, pp. 23-34, 2012.

[14] A. Haris, Perubahan Mekanisme Keringanan Uang Kuliah Tuggal (UKT) untuk Strata Satu dan Perpanjangan Pembayaran SPP untuk Program Pascasarjana Strata Dua dan Strata Tiga di Masa Pandemi COVID 19 Universitas Islam Negeri Maulana Malik Ibrahim Malang Semester Gasal 2020/2021. 2020.

[15] A. Haris, Pemberian Paket Data bagi Mahasiswa dan Sistem Pembelajaran Mahad Selama Pandemi Virus Corona Disease 2019 (COVID-19). 2020.

[16] 'Optimalisasi E-learning untuk Pembelajaran', Faculty of Economics Universitas Islam Negeri Maulana Malik Ibrahim Malang, Aug. 04, 2020. https://fe.uin-malang.ac.id/optimalisasi-e-learninguntuk-pembelajaran/ (accessed Oct. 03, 2020).

[17] Admin LP2M, 'LPM bersama LP2M Melaksanakan Pelatihan Pedagogik Bagi Calon Dosen UIN Malang Tahun 2020', Lembaga Penelitian dan Pengabdian Masyarakat UIN Mulana Malik Ibrahim, Aug. 14, 2020. http://1p2m.uinmalang.ac.id/2020/08/14/lpm-bersama-lp2mmelaksanakan-pelatihan-pedagogik-bagi-calondosen-uin-malang-tahun-2020/ (accessed Oct. 03, 2020).

[18] A. Abu-Al-Aish and S. Love, 'Factors influencing students' acceptance of m-learning: An 
investigation in higher education', International Review of Research in Open and Distributed Learning, vol. 14, no. 5, pp. 82-107, 2013.

[19] Asosiasi Penyelenggara Jasa Internet Indonesia, 'Penetrasi \& Profil Perilaku Pengguna Internet Indonesia', Asosiasi Penyelenggara Jasa Internet Indonesia, Jakarta, S 20190518, May 2019. Accessed: Oct. 06, 2020. [Online]. Available: https://apjii.or.id/survei2018s/kirimlink.

[20] D. Murdaningsih, 'Jaringan dan Biaya Internet Jadi Kendala PJJ', Republika.co.id, Yogyakarta, Aug. 04, 2020.

[21] Antara, 'Ketersediaan Internet Jadi Kendala Pembelajaran Jarak Jauh', Jawapos.com, Aug. 05, 2020.

[22] Ryn, 'Nadiem Akui Internet jadi Kendala Siswa Belajar di Rumah', CNN Indonesia, Jakarta, Jul. 30, 2020.

[23] D. Lase, 'Pendidikan di Era Revolusi Industri 4.0', SUNDERMANN: Jurnal Ilmiah Teologi, Pendidikan, Sains, Humaniora dan Kebudayaan, vol. 1, no. 1, pp. 28-43, 2019.

[24] A. Tait, 'Planning student support for open and distance learning', Open Learning: The Journal of Open, Distance and e-Learning, vol. 15, no. 3, pp. 287-299, 2000.
[25] K. Harto, 'Tantangan dosen ptki di era industri 4.0', Jurnal Tatsqif, vol. 16, no. 1, pp. 1-15, 2018.

[26] R. Setyaningsih, A. Abdullah, E. Prihantoro, and H. Hustinawaty, 'Model penguatan literasi digital melalui pemanfaatan e-learning', Jurnal ASPIKOM, vol. 3, no. 6, pp. 1200-1214, 2019.

[27] Joint Information Systems Committee, 'Developing digital literacies', Mar. 06, 2014 https://www.jisc.ac.uk/guides/developing-digitalliteracies (accessed Oct. 06, 2020).

[28] I. F. Rahmadi and E. Hayat, 'Literasi Digital, Massive Open Online Course, dan Kecakapan Belajar Abad 21 Mahasiswa Generasi Milenial', JURNAL STUDI KOMUNIKASI DAN MEDIA, vol. 24, pp. 91-104, Jun. 2020.

[29] E. Nurjanah, A. Rusmana, and A. Yanto, 'Hubungan literasi digital dengan kualitas penggunaan eresources', Lentera Pustaka: Jurnal Kajian Ilmu Perpustakaan, Informasi Dan Kearsipan, vol. 3, no. 2, pp. 117-140, 2017.

[30] G. Magnússon and J. Rytzler, 'Approaching higher education with Didaktik: university teaching for intellectual emancipation', European Journal of Higher Education, vol. 9, no. 2, pp. 190-202, Aug. 2018, doi: 10.1080/21568235.2018.1515030. 